\title{
A cidade moderna: espaço de reconfiguração do mito de Penélope
}

\author{
Denise de Carvalho Dumith*
}

\begin{abstract}
Resumo: O objetivo do presente ensaio é analisar o que a cidade moderna representa para a reconfiguração do mito de Penélope na literatura. Primeiramente será abordada a relação entre mito em geral e o surgimento das cidades. A seguir, tomandose como referência a Odisséia, de Homero, o hipotexto, desvelam-se as razões da gênese do mito penelopiano em especial, confrontando-a com sua reatualização em Janela do sonho, de Patricia Bins, seu hipertexto. Marshall Berman, Enrique del Acebo Ibáñez, Flávio Kothe e Jean-Pierre Vernant fornecem os principais embasamentos teóricos.
\end{abstract}

Palavras-chave: cidade moderna; mito de Penélope; espaço profano; espaço sagrado; mitoclastia.

\begin{abstract}
This essay aims at pointing out what the modern city represents for the reconfiguration of the literary Penelope's myth. Firstly, the relationship between myth in general and the formation of the cities is approached. Then, taking the hypertext the Odyssey, by Homer, as a reference, the main reasons for the genesis of this myth are showed. Finally, a comparison with its updating in Janela do Sonho, by Patricia Bins, is made. The ideas of Marshall Berman, Enrique del Acebo Ibáñez, Flávio Kothe and JeanPierre Vernant give the leading theoretical support to this study.
\end{abstract}

Keywords: modern city; Penelope's myth; profane space; sacred space; mythoclasty.

O objetivo deste trabalho é analisar a evolução do mito de Penélope na literatura sob o foco da cidade moderna em especial. Para tal fim, estabeleço um estudo comparativo entre as Penélopes da Odisséia (HOMERO, 2000) e de Janela do sonho (BINS, 1987), seu hipertexto. Assim sendo, esses dois cortes sincrônicos mostrarão dois momentos do mito, ao tempo de seu nascimento literário e há poucas décadas, traçando, deste modo, uma diacronia histórica.

A propósito, o conceito de modernidade e de moderno será observado conforme a definição de Marshall Berman:

\begin{abstract}
Existe um tipo de experiência vital - experiência de tempo e espaço, de si mesmo e dos outros, das possibilidades e perigos da vida - que é compartilhada por homens e mulheres em todo o mundo, hoje. Designarei esse conjunto de experiências como "modernidade". Ser moderno é encontrar-se em um ambiente que promete aventura, poder, alegria, crescimento, autotransformação e transformação das coisas em redor - mas ao mesmo tempo ameaça destruir tudo o que temos, tudo o que sabemos, tudo o que somos. [...] Ser moderno é fazer parte de um universo no qual, como disse Marx, "tudo o que é sólido desmancha no ar". (BERMAN, 1986, p.15).
\end{abstract}

\footnotetext{
* Doutoranda.
} 
Essa solidez que se pulveriza na modernidade remete, entre outras possibilidades, a modos de pensar e a comportamentos encarados como paradigmáticos, acima de quaisquer questionamentos. Por tal razão, paira no ar uma tendência iconoclasta de subverter as prescrições míticas. Em Aspectos do mito, Mircea Eliade expõe sua definição de mito, aquela considerada por ele "a menos imperfeita porquanto a mais ampla", qual seja: "o mito conta uma história sagrada, narra um fato importante ocorrido no tempo primordial, no tempo fabuloso dos 'começos'. [...] É sempre, portanto, a narração de uma 'criação’”. (2000, p.1213).

Desenvolvendo essa definição, Pierre Brunel pontua que: "o mito conta. [...] O mito explica. [...] O mito revela" (1998, p. XVI). Partindo, então, dessa concepção conceitual de que o mito é a narrativa de uma criação, de que é uma ontofania (revelação do ser) e de que a narrativa mítica implica em aceitação do ato de fé, está estabelecido o caráter religioso do processo. Devido a sua característica de fornecer respostas, o mito é tão antigo quanto as primeiras dúvidas humanas. Tais respostas, portanto, atendem à necessidade de organização do caos através da palavra, instrumento de inserção do homem no cosmos (mundo organizado). O caráter de religiosidade que reveste a entidade mitológica funciona como um dos fatores de agregação de povos ancestrais em torno de um espaço comum.

Esse espaço, porém, precisa ser organizado como lugar de convivência e de moradia. O homem, ser gregário, social, agrupa-se na cidade, onde fica delimitado o que é humano e o que é divino, daí decorrendo a construção de templos e de espaços sagrados nas casas. Em conseqüência, cria um mundo artificial - cultural -, que seja adequado para pôr em prática o modo de vida concebido (cf. IBÁÑEZ, 1993, p.21). Por sua vez, Mumford afirma que, "na cidade arcaica subjazia a crença de que o homem foi criado para louvar e servir a seus deuses. Aí se sustenta a razão última da cidade” (apud IBÁÑEZ, 1993, p.45).

No entanto, sem me deter sobre as aldeias paleolíticas, onde já se encontra o gérmen da cidade, com sua força aglutinadora centrípeta sociocultural que resulta na cidade, passo igualmente ao largo das cidades mesopotâmicas e egípcias para chegar à polis grega. Diferentemente dessas civilizações (mesopotâmica e egípcia), as cidades gregas se aproximavam mais do que Mumford qualifica de "medida humana", por não estarem tão condicionadas pela presença quase excludente dos reis-deuses, cujo poder onipotente produzia um desequilíbrio de forças em favor da cidade-templo (apud IBÁÑEZ, 1993, p.58), fazendo com que desapareça o indivíduo, condição facilmente verificável no Oriente ainda na atualidade. 
Aliás, é na polis grega que primeiro acontece a separação dos espaços sagrado e profano. Além do recinto do templo, na acropolis, e dos altares domésticos, surge o agora, a praça pública, lugar de exercício da cidadania, através da linguagem. Contudo, essa possibilidade não se estende a todos os moradores, já que as mulheres deveriam permanecer confinadas no gineceu. Claude Mossé, a esse respeito, comenta:

\begin{abstract}
Uma mulher respeitável não estaria presente a um banquete, mesmo se ele acontecesse em sua própria casa. Por imposição dos costumes, não deveria ela tomar a palavra em público, como o faziam as heroínas de Homero. A cidade, esse 'clube do bolinha' encerrou-as, definitivamente, no gineceu ${ }^{1}$. (1983, p.38).
\end{abstract}

O clã patriarcal, a casa, constitui um fator essencial de enraizamento. É onde se concretiza a união dos clãs, ou fratria. O lar deve estar implantado no solo, com a lareira ao centro, simbolizando o onphalos, o "umbigo da casa". Quando se acende o fogo, acontece a comunicação da casa com os deuses, pois aí se unem três níveis cósmicos: a terra, o ar, o fogo. O fogo representa também os antepassados, o que tornava os laços familiares mais arraigados, devido à autoridade absoluta do sagrado, seguida e imposta pelo pater potestas, que determinava a inviolabilidade do lar (cf. IBÁÑEZ, 1993, p.61).

Contudo, como observa Junito Brandão, “o adultério, in illo tempore era de gênero feminino" (1991, p.486). Certamente o era, porque o pai possuía o poder sobre o corpo de todos os que viviam sob seu teto. Tanto poderia relacionar-se com suas escravas, sem que isso se constituísse em adultério, quanto poderia decidir se o filho viveria ou não. O mesmo não acontecia com a mulher, simples moeda de troca, mero elo de união entre as famílias, comparável a uma simples incubadora. Assim sendo, para garantir a consangüinidade paterna dos aristoi, Jean-Pierre Vernant recorda que "Demóstenes cita uma lei que define os filhos legítimos, como os que 'se originam de uma mulher concedida através da engúe' [contrato oral] por seu pai” (1992, p.48-49). Em outras palavras, o título de cidadão somente seria concedido ao fruto da união de um cidadão, com a filha de outro cidadão.

Em razão dos constantes deslocamentos para guerrear, os homens gregos precisavam manter suas mulheres fiéis - de qualquer modo - para garantir a paternidade da prole (cf. VERNANT, 1992, p. 66). A fim de doutriná-las, mais especificamente as eugenei, as bemnascidas filhas de cidadão, surge, propaga-se e perdura, como resposta aos desejos da elite, o mito de Penélope.

Homero (ou a entidade assim intitulada) compila narrativas orais na Odisséia, cuja personagem Penélope espera pelo marido Odisseu - fielmente - durante os dez anos da

\footnotetext{
${ }^{1}$ Minha tradução de: "Une femme respectable n'assistait pas à un banquet, même s'il se déroulait dans sa propre maison. 'A fortiori' ne devait-elle pas prendre la parole en public, comme le faisaient les héroïnes d'Homère. La cité, ce "club d'hommes", les avait définitivement enfermées dans le gynécée".
} 
Guerra de Tróia, e por mais dez, tempo decorrido na viagem de regresso ${ }^{2}$. Finda a guerra, porém, um grande número de pretendentes, 99 ou 108 (se considerarmos que eram todos nobres, príncipes), instala-se em Ítaca $^{3}$, depredando os bens de Odisseu em intermináveis banquetes (os bens constituíam-se, além do palácio e dos escravos ${ }^{4}$, em hedna, os semoventes, e em dora, os artigos brilhantes, as jóias).

O conjunto de qualidades que Penélope apresenta redime a mulher, descendente da grei de Pandora ${ }^{5}$, o "belo mal", por portar em si a mente do cão (nóon kynóon) e a conduta dissimulada (ethos epíklopon) do ladrão, obsequiadas por Hermes (cf. HESÍODO, 1995, p. 136-9). Penélope mostra-se, então, uma mulher digna de Odisseu, aquele que possui a metis ${ }^{6}$, além da arete (excelência em si), esta última, atribuição unicamente masculina. Ela recebe a metis através da convivência com o marido. Se Odisseu é o autor da estratégia da construção do cavalo de madeira para invadir Tróia, de Penélope é a idéia de tecer uma mortalha para o sogro Laertes (embora atribua o estratagema à inspiração divina), finda a qual escolheria um novo esposo - e quem compartilhasse do seu leito reinaria em Ítaca. Porém, à noite, destece todo o trabalho feito durante o dia. Com tal artimanha, retarda as indesejadas bodas por três anos, tempo que possibilita o retorno de Odisseu.

Penélope é uma mulher plenamente bem sucedida em todos os papéis que lhe cabem, a saber: o de boa filha de Icário, o de mãe exemplar de Telêmaco, o de esposa fiel de Odisseu, além de um inusitado papel de competente administradora. Tais sucessos justificam-se, pois sua inspiradora e protetora era Atena, a deusa da sabedoria. A origem espartana da rainha explica sua atitude virago (viril -, neste caso um grande elogio) de administradora do oikos de Odisseu. Mas Penélope não era dona de seu corpo. Portanto, quando Telêmaco atingisse a maioridade, aos 21 anos, ela deveria retornar para a casa do pai, oportunidade para o filho

\footnotetext{
${ }^{2}$ Existem outras versões, segundo as quais Penélope teria se relacionado sexualmente com alguns, com vários ou com todos os candidatos ao seu leito. Neste ensaio será observada estritamente, porém, a narrativa épica homérica.

${ }^{3}$ A mítica Ítaca é uma ilha, lugar utópico por excelência. Não é por coincidência que Thomas Morus situa sua Utopia em um lugar modificado artificialmente por mãos humanas, pois, a princípio, tratava-se de um istmo, cuja ligação com a terra foi interrompida através de um canal artificial. Além disso, a atual ilha grega chamada de Ítaca não coincide com aquela descrita na Odisséia, conforme estudos de Robert Bittlestone, James Diggle e John Underhill, que juntos publicaram Odysseus Unbound: The Search for Homer's Ithaca. Cambridge University Press, 2005, conforme o site http://odisseus-unbound.org/PDFs/Euphrosyne_Review_Portuguese.pdf, consultado em 01.12.06, às $16 \mathrm{~h}$.

${ }^{4}$ Um nobre grego costumava ter 18 escravos e 2 metecos, conforme ENGELS apud IBÁÑEZ (1993, p. 63).

${ }^{5}$ Pandora é entregue aos homens como um presente-castigo de Zeus, em contrapartida ao roubo do fogo por parte de Prometeu ao Cronida, para dá-lo aos humanos. Assim sendo, nenhum homem poderia viver sem ela, devido a sua beleza, mas não poderia ser feliz com ela, encarnação do mal.

${ }^{6}$ Capacidade de compreender as situações e adaptar-se a elas com extrema rapidez, o que pode ser resumido em uma forma de sabedoria, também traduzida por prudência ou solércia.
} 
herdar o trono. Seu comportamento fiel, transgressor para a época, instaurou-se como modelo e vem educando as gerações femininas por cerca dos trinta séculos que nos separam de Homero, cumprindo a função pedagógica do mito em geral, segundo Mircea Eliade, considerando que "a função soberana do mito é revelar os modelos exemplares de todos os ritos e de todas as atividades humanas significativas: tanto a alimentação como o casamento, o trabalho, a educação, a arte ou a sabedoria" (2000, p.14-15).

Uma das reatualizações desse mito acontece em Janela do sonho, publicado em 1986, sob autoria de Patricia Bins, autora de origem inglesa radicada em Porto Alegre. Se o romance contém uma fábula simples, a trama apresenta-se sobremaneira intrincada, como se fosse um quebra-cabeças, em que a Teoria Literária e as técnicas de narração funcionam como fios de Ariadne nessa obra-labirinto, onde o prazer de perder-se quase se equipara ao prazer de decifrá-la.

A história constitui-se através de três níveis narrativos. Assim sendo, há uma narradora-autora extradiegética (cf. GENETTE, 1972, p.238-239) que se assina Patricia Bins ao final. No segundo nível, intradiegético, insere-se a segunda narradora, chamada Maria. No terceiro, chamado hipodiegético, figuram as ações da mesma Maria, agora na qualidade de protagonista, bem como aquelas das demais personagens em seus respectivos espaços. A fábula que Maria conta, em tempo psicológico (pleno de analepses e prolepses), é a história de sua vida. Na atualidade narrativa, Maria é uma mulher idosa que repassa seu passado, seus erros, com a intenção de purgar as próprias culpas, à guisa de catarse, com a intenção de preparar-se para a morte que pressente próxima. Realiza, então, sua catábase, nekya, a viagem vertical às profundezas de seu eu, inferno interior, perfazendo assim sua odisséia pessoal. Projeta-se, no passado, na filha que se suicida, mas, para o futuro, projeta-se em três mulheres bem resolvidas quanto a seus problemas, pois encaram-nos com lucidez, autoquestionando-se, sem, contudo, culparem-se excessivamente. Essa divisão especular do eu de Maria remete tanto à divisão tripartite da personalidade freudiana, quanto aos papéis em que mais gostaria de ter-se realizado, ou seja, os de mãe, esposa e profissional.

O espaço em que se desenrola o romance é urbano, oscilando entre o público e o privado. Nessa cidade, consoante a tendência cultural, o espaço público destina-se ao gênero masculino por excelência até uma determinada geração, enquanto que o feminino, no caso de Maria e das outras mulheres de seu tempo, é confinado no lar, ou no sobrado em que reside. As personagens que Maria inventa, porém, pelo fato de serem contemporâneas a seus filhos, já ocupam o agora moderno, significando simbolicamente terem alcançado a visibilidade tão almejada. 
Em Janela do sonho, a praça é o espaço público descrito com recorrência, através da voz de todos os personagens. Na longa rememoração de Isaías, assim é descrita:

\begin{abstract}
Um amargo na boca, embora o sol nesta praça. Sol meio ralo, mel diluído, clara gema pousa sobre o capim dos canteiros, ama Fernando Pessoa quando diz "Pobres das flores nos canteiros regulares. Parecem ter medo da polícia...", ou algo semelhante, não conhece bem as palavras, aliás péssima memória desde criança; aqui os canteiros são regulares mas a vegetação não, ninguém apara a grama, não se cuida das árvores, a praça tem este ar selvagem, só o monumento sobressai, em bronze, solene, urbano, talvez de inspiração greco-romana. A praça foi uma das primeiras da cidade, no centro dos três poderes constituídos, a sede do governo, o palácio da justiça e a assembléia legislativa, além do teatro e da catedral metropolitana. Estranho, nunca poderia imaginar-se interessado em descrever esses elementos, jamais tiveram importância para ele, afinal viveu aqui a vida inteira, não via nada, por ter os olhos acostumados. Por que hoje atento? (BINS, 1986, p. 20)
\end{abstract}

Através da descrição que Isaías fornece dos prédios que constituem o poder público, o religioso, além do centro cultural dispostos no entorno da praça, infiro que confere com a Júlio de Castilhos, em Porto Alegre. Essa inferência é reforçada quando a narradora menciona por três vezes, em ocasiões diversas, o índice 'minuano', vento típico das plagas sulinas. Além disso, o tempo coincide com o fim de inverno gaúcho: "sol de final de agosto, mais um mês e virá a primavera. Olha em torno, os jacarandás começam a florir cedo, seus pequenos rotos roxos fazem um tapete a seus pés. Sobre o verde da relva trama-se o estranho tecido vivo" (BINS, 1986, p.38).

Trata-se de uma manhã, na qual "a cidade acorda depressa, o trânsito enlouquece, gente corre em todas as direções, rebanho guiado por mil donos, cada qual quer extrair o máximo pelo mínimo" (BINS, p.21). Isaías aproveita a ocasião para dar vazão ao sentimento de inconformidade que nutre em relação à acelerada modernização da cidade. Enquanto observa a incorporação de elementos novos na paisagem, vêm-lhe à mente elementos do passado:

\footnotetext{
O relógio da catedral soa oito vezes. Ergue-se, tropeça numa pedra escondida, rala a ponta do sapato, droga!, se incorpora ao bando, corre, chega ao edifício novo, lembra-se da velha construção que havia antes, conviveu desde menino com aquela casa tão próxima à sua, um sobrado elegante, o pai costumava apontar os detalhes, vitrôs, portas, colunas, art-nouveau puro, dizia. Por que o derrubaram? Hoje, trinta andares, gaiolas, somos pássaros cativos; em frente ao elevador a fila imensa, um arrepio de vozes, faltou luz; terá que subir a pé os lances, os sons se esparramam, falam em pane geral, em comício de estudantes, vamos de volta à praça, como trabalhar? (BINS, 1986, p. 21-22)
}

Isaías configura-se em um flâneur, "observador dos outros e de si mesmo" que espera a amante enquanto observa a multidão, mas também é observado, embora seja por um "sujeitinho" que o chama de "bobo", para participar de um ato político (p.22). A partir de suas reflexões, o filho de Maria externa esse "sentimento de passividade e desesperança que tomou conta de tantos de nós nos anos 70. Inútil tentar resistir às opressões das injustiças da vida 
moderna, pois até nossos sonhos de liberdade não fazem senão acrescentar mais elos à cadeia que nos aprisiona" (BERMAN, 1986, p.34-35).

Na cama, Isaías é voyeur, dedica-se a avaliar seu desempenho, ao invés de entregar-se ao ato do prazer sem racionalizações demasiadas. As correntes que o aprisionam decorrem já da infância, de um não resolvido sentimento de Édipo (infelizmente para ele, identificado pela esposa, graduada em psicologia). Seu papel no comício, na cidade, é o de vítima sacrifical ${ }^{7}$, morto pela violência urbana, no confronto entre a turba e o poder.

Nesta altura da diegese, surge a personagem Myriam (antropônimo que significa Maria, em grego - detalhe a reforçar a projeção da protagonista-narradora). A jovem também deseja encontrar Isaías, seu amante, na praça, que assim descreve:

O sol ilumina o puro bronze patinado, azinhavrado, cavalos, dragões, serpentes se retorcem, agonia da morte transposta para o material perene. Myriam observa crianças, algumas crianças que brincam montadas nos animais, sem o perigo de viver, o céu azul anil, poucas nuvens; ao redor, o palácio, o teatro, a catedral, as últimas casas de outros tempos espremidas pelos edifícios, concreto, vidro, aço; que será destes prédios no futuro? Que terríveis ruínas. (BINS, 1986, p.27)

Devido ao fato de integrar uma geração de mulheres que vêm conquistando seu lugar no espaço público da cidade, solidariza-se com os demais participantes do protesto, enquanto reflete e lamenta a destruição das casas sufocadas pelas novas construções. Contudo, de acordo com Jean Cocteau, "nada se parece mais a uma casa em ruínas do que uma casa em construção"8 (apud ANDRADE, 1990, p.28). Portanto, não vislumbro nessa destruição do antigo apenas possibilidades negativas, além de que o novo não pode ser barrado: quanto mais for sufocado, mais violenta será sua eclosão.

Ato contínuo, Myriam pergunta-se: "Isaías, como encontrá-lo em meio à multidão?" (BINS, 1986, p.28). De certa maneira, mostra-se perdida, mas tem um objetivo específico ali, o que lhe dá uma certa direção. Na seqüência da trama, a praça novamente é palco - de espera -, quando Isaías procura Myriam em cada rosto dessa multidão que se interpõe entre ambos (p.37). Adiante, torna-se pano de fundo para o encontro do casal, destoando do contexto pouco favorável a encontros amorosos:

O povo não desiste apesar do frio, do vento, do tépido sol, da fome (quem interrompe para se alimentar é desertor), das confusões ideológicas (há tantas facções, tantas opiniões, porém de certa forma unido em favor da causa maior) dos homens uniformizados, armados, que cercam a praça arrogantemente. (BINS, 1986, p.40)

\footnotetext{
${ }^{7}$ Northrop Frye, em Anatomia da crítica, pondera que "na concepção apocalíptica da vida humana encontramos três espécies de realização: individual, sexual e social. No mundo humano sinistro um pólo individual é o chefe tirânico [a exemplo do chefe de Isaías], o outro pólo é representado pelo pharmakós ou vítima sacrifical, que tem de ser morta para fortalecer os outros" ([s.d.], p.149).

${ }^{8}$ Minha tradução de "rien ne se ressemble plus à une maison en ruines qu'une maison em construction...".
} 
Percebe-se no excerto, a presença opressiva do poder institucional, a possibilidade crescente de violência em contraponto à superação do conjunto de problemas coletivo pelo pessoal. Embora Myriam e Isaías estejam mergulhados na multidão delirante, são apenas dois, plenos pelo sentimento correspondido.

A seguir, a narradora acrescenta um detalhe caro aos porto-alegrenses, na paisagem que descreve:

A chuva amaina, nesse final de tarde e, para além dos edifícios, para além dos antigos sobrados, para além do teatro em ruínas, do palácio, da catedral, da assembléia legislativa, da praça da matriz, para além do povo e suas lutas, há o rio a fluir sem tempo. Uma repentina claridade tinge o céu encoberto que se reflete sobre a água, adivinhada pela multidão novamente em delírio. (BINS, 1986, p.79)

O rio segue seu curso, cujo fluxo constante coloca-o acima de quaisquer ideologias.

Por isso flui sem tempo, transcendendo a cultura, o poder constituído e a religião dos povos que cruzam seu percurso trans-histórico e transespacial, a exemplo do rio Guaíba, em Porto Alegre.

Em outro ponto, Rachel, de profissão professora, outra das projeções de Maria, participa do mesmo ato de protesto, assim percebendo seu espaço e seu momento:

O luar ilumina o puro bronze patinado, azinhavrado, cavalos, dragões, serpentes se retorcem, agonia da morte transposta para o material perene. Ao redor, o palácio, o teatro em ruínas, a catedral, a assembléia legislativa o palácio da justiça, as últimas casas de outros tempos espremidas pelos edifícios, concreto, vidro, aço. O sobrado.

Na praça, o povo leva tochas de fogo e, passeando por entre a multidão, a polícia montada, guardadora da ordem. O clima se acirra, o interno e o externo, talvez pela ausência de luz elétrica, pela solidão da noite alta, das ruas silenciosas; na cidade, pouquíssimos pontos iluminados, mas estrelas sim o universo por companhia. (BINS, 1986, p.119)

A praça é, tal como para Isaías, lugar de reflexões para Rachel, se bem que, para a moça, os pensamentos ultrapassem a esfera individual e adquiram um caráter mais amplo, ontológico:

Os cavalos percorrem a quadra e, vez que outra, embrenham-se entre o povo que canta, gesticula, se abraça, à espera do milagre. Que milagre? O retorno à normalidade, à paz social. Mas, que paz? Normalidade sempre foi a guerra, a violência, a desigualdade, a luta pelo poder, onde poucos dominam muitos. O retorno à luz, à grande luz fraterna. Seria possível? Estas pessoas aqui reunidas simbolizariam o amor eternamente buscado? (BINS, 1986, p.120)

Adiante, os cavalos simbolizam o terror que se instala, através da violência:

Começos de um motim: cavalos da polícia relincham, assustados, ante o tiroteio vindo não se sabe de onde, de que lugar da praça. Súbito, galopes desenfreados, confusos gritos, mais tiros, mais gritos, o palanque feito de tábuas mal e mal ajuntadas se desfaz em meio à multidão. Para não sofrer o horror do fogo das tochas soltas na hora do acidente, as pessoas escapam, unemse, apartam-se em pânico. Os cavalos correm, sem dono. [...] A coisa entortou. Fogo, tiros, o pânico dos cavalos. (BINS, 1986, p.127-128)

Os cavalos, descontrolados, galopam por entre a multidão. Algumas pessoas procuram debelar o fogo que se alastra no palanque, as leves tábuas se transformam em chamas. O povo se comprime, querendo se proteger. (p.129) 
A personagem Martha, nora de Maria, de profissão psicóloga e seu terceiro desdobramento, observa a manifestação à distância, desde a janela de Maria, pois cabe-lhe cuidar dos dois filhos, além de assistir à sogra naquele momento. Avista "o povo na praça a reclamar, a reivindicar terra, pães, tetos" (BINS, 1986, p.133), reconhecendo na praça pública o local de reunião para alcançar visibilidade imediata frente aos poderes constituídos, além de ser o locus de encontros ou desencontros pessoais. Quer dizer, a praça cumpre uma função dupla, unindo os pólos público e privado, o que vem a romper com o conceito clássico do agora, ponto de encontro da elite, pois os cidadãos que a freqüentavam eram somente os homens nobres.

Tal consideração é reforçada pelo comentário de Hannah Arendt acerca de idos tempos, a partir dos escritos de Xenofonte:

A principal divisão era entre a vida vivida dentro de casa, no lar, e a vida vivida fora, no mundo. Somente esta última era considerada como digna de um homem e, naturalmente, não havia a noção de igualdade entre o homem e a mulher, que é um pressuposto necessário para a idéia da divisão do trabalho. (ARENDT, 2001, p.57)

Maria nunca se afastara do lar, do sobrado, para trabalhar. Ao pai cabia movimentar-se no terreno de Hermes, ao praticar o comércio no piso térreo. Porém, "aos dezoito anos, levou o marido, risonho, para aquela casa triste" (BINS, 1986, p.45). Portanto, ao levar o marido para a casa de seu pai, subverte o casamento patrivirilocal clássico, quando as mulheres saíam da casa paterna para habitar a casa do sogro. Como exemplo, cito Penélope que deixa a casa do genitor, Icário, em Esparta, para integrar o clã de Laertes, pai de Odisseu, em Ítaca.

Devido a seu confinamento, ocupa o "posto de espiã" (BINS, 1986, p.32), expressão reiterada após (id., ibid., p.78), ao modo de um flâneur a observar o panorama. Porém, é um par de olhos, para fora, para dentro, o que ultrapassa a flânerie. Para fora do sobrado, através da 'janela do sonho', para dentro de si, através da descida ao seu inferno interior. Tanto o isolamento, quanto o desconhecimento do próprio eu, impedem-na de ter uma visão mais abrangente da realidade, sem, no entanto, anular-se como o badaud, que perde a identidade em face da multidão (cf. FOURNEL apud KOTHE, 1985, p.94). Pelo contrário, Maria não se mistura ao público e busca identificar-se. Sua visão, no entanto, é fragmentada, o que concretiza nos quadros que pinta:

\footnotetext{
Azul, azuis, eu os pintei em tantas telas na época em que buscava, como Seurat, fragmentar ou decompor os objetos, devolvendo-os, depois, íntegros à sua natureza. Então, os detalhes eram o todo, como agora quando destaco as pessoas que preciso inventar e as estilhaço, num estranho processo pontilhista. Poderei, a certa altura, induzi-las à vida, à identidade que ainda ignoro? Como ignoro a minha, porque a construo de instante em instante. (BINS, 1986, p.32-33)
}

Atribuo à imposição social de permanecer circunscrita ao perímetro doméstico, a dificuldade de Maria realizar sua individuação, de reconhecer-se como indivíduo, na 
unicidade e multiplicidade do sujeito humano. Para construir-se identitariamente, utiliza-se da myse en abyme para fragmentar a própria personalidade em outras três. Ao atingir o sucesso na empreitada de criar outras vidas, tramando penelopicamente seus fios, alcança a tão almejada identidade como escritora.

Outro aspecto importante a considerar é que a cidade, além de se configurar em espaço propício para realizações concretas, também favorece outra instância, a do sonho. As pessoas em geral - e as dramatis personae por extensão - têm o costume de devanear acerca de determinadas cidades como se tratando de lugares paradisíacos, ou, ao conhecer uma cidade durante uma ocasião feliz, a cada vez que ouvem ou lêem seu nome, relembrar o momento prazeroso, estabelecendo uma associação sensória. Este é o caso de Buenos Aires, para Martha:

O tango, dançar uma noite inteira em Buenos Aires com Isaías, naquela época se amavam ainda, ou não chegaram a se amar? Foi na lua-de-mel, as folhas secas dos plátanos cobriam as calçadas da Avenida Santa Fé, Martha juntou algumas, colocou na bolsa como lembrança. (BINS, p.57-58)

Igualmente Isaías lembra da capital portenha como espaço de felicidade ao relacionarse fisicamente com a amante Myriam, embora tendo lá passado a lua-de-mel com a esposa Martha. A cidade conota o compartilhamento amoroso, independente da pessoa com quem se encontre. Embora distante desse lugar, a música exerce o papel de aproximação geográfica:

- Vamos sintonizar na El Mundo, de Buenos Aires. A essa hora talvez se consiga qualquer coisa clássica.

- Um tango ou uma valsa, um blue. Para dizer a verdade, quero algo romântico, até vulgar.

- Mas não há nada de vulgar neste encontro, Myriam, isso me ofende. (BINS, 1986, p.91)

Por outro lado, a cidade pode ser espaço de desilusão, a exemplo de Matheus, o marido de Maria, que volta a Budapeste para reencontrar suas supostas raízes. A voz narradora assim resume a situação:

Matheus retornou a Budapeste, após o falecimento dos pais, à procura de parentes. Morrera todo o mundo; disse numa carta que fora até a Rua Uromi onde antes habitavam, sentiu-se absurdo ao bater na porta cerrada, quem atendeu só meneava a cabeça, de nada sabia, nunca ouvira falar na família; a casa era de cômodos então, ninguém conhecia ninguém. Visitou bares da adolescência, a antiga escola, residências de amigos, um vazio. Aquele homem alegre escreveu notícias tristes à mulher e aos filhos, no Brasil. A volta à terra natal, no entanto, consolidara a certeza de que era, em qualquer lugar, um exilado. Desapareceu. Enviava, quando podia, algum dinheiro. (BINS, 1986, p.60)

O continente europeu em geral transforma-se em lugar de perdição - morte moral -, da venalidade do corpo à guisa de recurso para garantir a sobrevivência, conforme revelação posterior do próprio Matheus:

Impregnei-me das tristezas do mundo, morri tantas vezes, desde que fui à Europa: começou talvez nas peregrinações à procura de parentes em Budapeste a minha solidão absoluta, dividido entre duas pátrias, fragmentado entre a pessoa que fui e aquela que penso ser. 
Confesso que me entreguei aos prazeres da carne, destituído de qualquer conotação amorosa. Freqüentei bordéis, na cidade natal, e após, nos lugares por onde andava à procura de mim mesmo. Recordo o quanto sofri, perturbado por minhas absurdas infidelidades e por me mascarar de bom marido, naqueles cartões enviados esporadicamente. Em Colônia, vivi um mês à custa de uma dama da noite que cobrava, pelo alimento e a estada, o preço do meu corpo. Quando, afinal, decidi ir embora para Gênova, a mulher, aos prantos, quis morrer. Fui, resolvido a embarcar no primeiro cargueiro que aparecesse, apavorado com a criatura em que me transformei. A viagem de volta me convenceu de que só encontraria felicidade junto à família. (BINS, 1986, p.123)

Contudo, não é o que revela à mulher, por ocasião da ausência, eufemizando sua situação:

Frankfurt - 10 de fevereiro

De minha passagem por Frankfurt não posso enviar nada, querida, além deste postal e meu amor. Matheus.

Colônia - 27 de fevereiro

Procuro engatilhar algum trabalho para o retorno, contatos com importadores. Por isso, ando de cidade em cidade, e lamento não ter notícias de vocês. Escreverei longa carta quando estiver mais calmo. Beijos, Matheus.

Gênova -7 de abril

Maria, reservei passagem num cargueiro italiano, o mais barato que há por aqui. Perdão, minha querida, por não ter escrito no último mês. Não posso explicar o que ocorreu comigo. Espero ansioso revê-la e os amados filhos. Baci. Matheus. (BINS, 1986, p.69)

É cristalino, através do trecho acima, o fato de que Matheus não (se) questiona a respeito do provimento das necessidades essenciais da família no Brasil. Tal encargo recai sobre os ombros de Maria, única responsável pelo sustento dos filhos, além dela própria.

Por outro lado, obra da ironia, aquela que tem o epíteto de cidade maravilhosa é o local da morte para Matheus, após longo sofrimento:

No Rio de Janeiro acabei encontrando um empreguinho mal pago onde permaneci anos a fio; perdera, além do resto, minha ambição, minha coragem. Sucumbi ao medo. Dolorosa angústia me tomava, rondava meus mínimos e desatinados passos. Centenas de vezes fui tentado a regressar. Não voltei. Enfim, me uni a uma boa mulher com quem tive duas meninas. Me amou, eu não soube retribuir. Nestes últimos meses, ela se transformou em mãe e enfermeira. A doença sem nome me consumiu lentamente. Agora, no leito de morte, escrevo essas palavras na esperança de chegarem a você. (BINS, 1986, p. 124)

Ele não percebera a tempo, ao contrário de Odisseu, que suas raízes mais profundas encontravam-se no leito conjugal. Não, sua percepção é tardia. Matheus, ao deslocar-se, desenraiza-se, permitindo que se rompa o vínculo do amor. Trai, mas não admite ser traído, sentimento atávico ainda comum.

Uma das razões por que Maria se relaciona com outros homens dos quais nem relembra o nome remete ao rato, habitante mais numeroso das cidades, personagem constante na literatura ${ }^{9}$, onde presentifica a sensação de ser roído, devorado aos poucos pela cidade,

\footnotetext{
${ }^{9}$ Conforme o destaque recebido nos livros Os ratos, de Dyonélio Machado; Angústia, de Graciliano Ramos; Cidade sitiada, de Clarice Lispector; Mês de cães danados, de Moacyr Scliar, dentre outros.
} 
devido às condições degradantes que oportuniza a um grande número de seus indivíduos. Maria, no entanto, associa o rato à sexualidade, de acordo com o que Chevalier e Gheerbrant pontuam: "como assinala Freud em $O$ homem dos ratos (cinco psicanálises), este animal, tido como impuro, que escava as entranhas da terra, tem uma conotação fálica e anal [...] É o que faz com que seja freqüentemente [associado à] atividade noturna e clandestina” (1999, p.770).

Maria, através da descoberta da nudez paterna, liga o sexo à morte, ao sangue do rato:

Houve um rato, aliás uma ratazana enorme no seu quarto, lembra-se, chamou o pai, ele veio, nu, um homem enorme, o duplo medo. Era seu pai, aquele, o alemão. Foi buscar o revólver, deu um tiro certeiro, a ratazana caiu em cima da cama, pingava sangue, boca aberta agonizante. O pai riu, impávido, pegou o animal pela cauda, atirou-o para a rua; disse: pronto, está tudo terminado, vou lavar as mãos. Depois ela olhava o céu, a lua redonda como o primeiro círculo que desenhou no tempo em que era inteira. (BINS, 1986, p. 68)

Esse acontecimento possui uma importância capital na trama de Janela do sonho, porquanto é retomado em duas outras ocasiões, basicamente nas mesmas palavras, como costuma acontecer na descrição de situações marcantes, de cunho traumático. Assim sendo, a possibilidade do gozo físico estabelece uma conexão com a morte, ou a pequena morte, conforme ao que George Bataille pontua:

Popularmente, o orgasmo tem o nome de "pequena morte". Ou não há amor ou ele está em nós, 'como a morte', um movimento de perda rápida, deslizando rapidamente para a tragédia, detendo-se apenas frente à morte. Tanto é verdade que entre a morte, e a "pequena morte", ou o chavirement, que embriagam, a distância é insensível ${ }^{10}$. (1995, p.264-265)

Por essa razão, Maria não consegue entregar-se, nem gozar no ato sexual ${ }^{11}$. Maria, como o rato, não quer morrer "al primo incontro" 12 . Seja no primeiro encontro oficial, quando a virgem sangra na noite de núpcias, seja naquele do retorno do marido, ocasião propícia para a fusão da carne e do espírito. Matheus, esse Odisseu verde-amarelo que não soube atender às necessidades de sua mulher, não ganha a 'guerra', não descobre suas raízes, ao retornar não encontra Penélope-Maria amorosa, fielmente à espera:

Matheus chegara à noite, tarde da noite, e a sobressaltou. As crianças dormiam, e ela, pega em flagrante; era um homem banal que alugara o quarto, ela precisava sobreviver. De repente na

\footnotetext{
${ }^{10}$ Minha tradução de: "Populairement, l'orgasme a le nom de "petite morte". [...] L'amour n'est pas ou il est en nous, 'comme la mort', un mouvement de perte rapide, glissant vite à la tragédie, et ne s'arrêtant que dans la mort. Tant il est vrai qu'entre la mort, et la "petite mort", ou le chavirement, qui enivrent, la distance est insensible."

${ }^{11}$ No futuro seria estabelecida uma conexão entre o pintor Seurat, sob cuja técnica Maria passaria a representar seus trabalhos pictóricos e a cena da morte do rato. Decompondo o nome Seurat, num trocadilho, Patrícia Binsnarradora mescla as línguas português e inglês: $\mathrm{s}(\mathrm{e})$ eu rat (rato) [fosse], (informação da autora através de entrevista pessoal, em 03.02.00). Maria sentir-se-ia no lugar do roedor. A satisfação do pai pelo ato de morte concluído, o sangue sobre a cama, tudo se interliga numa fantasia castradora que a impedia de dar-se (como o filho Isaías). Informação da autora através de entrevista pessoal, em 03.02.00.

${ }^{12}$ Per non morir al primo incontro: refrão da ária de Madame Butterfly, de Giacomo Puccini, ópera predileta de Maria.
} 
memória o ar de espanto do marido, seu desespero absoluto. Ela chamou da cama, Matheus, Matheus, espere um pouco. Eu o amo. Eu explico. (BINS, 1986, p.70)

O leito conjugal do casal moderno não está, literal nem metaforicamente, construído com a solidez da oliveira ${ }^{13}$ pelo próprio noivo no tempo clássico. Porém, tanto na Antiguidade, quanto na atualidade narrativa, o adultério recebe um enfoque diferente conforme o sexo de quem o pratica.

Deve-se considerar, contudo, que Maria não é uma prostituta segundo os moldes tradicionais, que vai às ruas vender o corpo, da maneira como Baudelaire aborda em "A musa venal", comentada por Benjamin, a qual, para ter sapatos, vende a alma (apud KOTHE, 1985, p.64). Mas essa condição 'privilegiada' da personagem acontece porque possui um teto herdado. Entretanto, para a moral da época, estimo que meados do século XX, configura-se em uma mulher libertina, desde a traição ao marido. Apesar de não se expor como mercadoria, a sociedade não lhe confere o direito de exercer sua sexualidade, sequer no interior de sua casa.

A vizinhança não aceita com bons olhos o fato de Maria complementar sua renda tão exígua com o aluguel de quartos do sobrado a homens 'solteiros', já que o ex-marido não lhe fornece qualquer apoio financeiro, e ela, além de sustentar-se, deve prover, pelo menos, as necessidades básicas dos dois filhos. Torna-se difícil obter o montante adequado apenas da renda de peças de tricô que tece. Dessa forma, à maneira de um diferencial no aluguel, concede seu corpo aos inquilinos como um upgrade em relacionamentos descartáveis e, através deles, obtém prazer físico.

Aos olhos da filha Deborah, a qual relaciona-se com os amantes da mãe para vingar-se do afastamento do pai (sentimento análogo ao da personagem grega Electra), Maria aproveita "o lado bom da vida": "I. morre de medo que Mári descubra alguma coisa a nosso respeito, por isso nos convida para o cinema ou para jantarmos juntos. Restaurantes grã-finos, não poupa dinheiro e nos cumula de atenções" (BINS, 1986, p.107).

A face dandy de Maria, na qual "agradar é um elemento importantíssimo" (KOTHE, 1985, p.119), também é revelada pela filha, ao comentar que:

Maria não se priva de nada, deu um jeito até de arrumar uma cabeleireira que vem em casa penteá-la, fazer-lhe as unhas, paga mensalmente, não perde a mania de burguesa e artista, ainda por cima. O que gasta em material de pintura, Nossa Senhora: telas, e tubos de tinta, e pincéis, sempre aquele pontilhismo inspirado em Seurat. Jamais vendeu um quadro, pendura tudo o que

\footnotetext{
${ }^{13}$ Penélope, desconfiada da identidade do estranho que alega ser seu marido, ordena à criada mudar a cama de lugar, colocando-a fora do quarto, contra o que Odisseu manifesta-se com veemência. Ele próprio havia construído um dos pés do leito entalhado no tronco de uma oliveira ainda enraizada ao solo, impossibilitando, portanto, sua movimentação (cf. HOMERO, 2000, p. 386-387). A metáfora remete à solidez com que foi construída a união do casal,
} 
produz. Uma loucura. Será que tem talento, ou é apenas pose, fuga? Não tenho capacidade de julgar. (BINS, 1986, p.65)

Deborah, por sua vez, dá aulas particulares de matemática para crianças, contudo sente-se humilhada por ter que cobrar (BINS, 1986, p.65). Incapaz de prover o próprio sustento, tão inábil quanto a mãe para deslocar-se no reino de Hermes, suicida-se por estar grávida e não querer que seu filho nasça sem pai, tal como ela cresceu:

Meu gesto é consciente, tão consciente quanto possível, nas circunstâncias atuais de desespero e de profunda tristeza. Vês que não posso te chamar Mamãe por tudo que houve nos últimos tempos. A saída que escolhi parece a única viável. Se I. me amasse, seria diferente, até me casaria com ele, afinal é pouco mais velho do que eu (e muito mais moço que tu), ou viveria com ele simplesmente, sempre achei importante a figura paterna (sofri na carne esta ausência) para uma criança. A que carrego dentro de mim (amo-a demais), por infelicidade, morrerá. Lastimo cometer o duplo crime [...] Sinto a pureza da podridão. (BINS, 1986, p.109-110)

Longe de ser covardia, reveste-se da oximórica "pureza da podridão" a atitude antiheróica de Deborah ao suicidar-se. A discutível fraqueza humana que encerra o suicídio associa-se à modernidade, no pensamento de Baudelaire analisado por Benjamin, ao contrário do que acontecia na Antiguidade:

Os obstáculos que a modernidade contrapõe ao elã produtivo natural do ser humano encontram-se em desproporção às forças dele. É compreensível que o indivíduo chegue a fraquejar, refugiando-se na morte. A modernidade deve estar sob o signo do suicídio, que apõe o seu selo a um querer heróico que não faz concessões à atitude que lhe é hostil. Tal suicídio não é desistência, mas heróica paixão. É a conquista da modernidade no âmbito das paixões. (BENJAMIN apud KOTHE, 1985, p.99)

Após a morte da filha, Maria encerra-se dentro de seus muros, representados pelo sobrado decadente: "agora erguem-se os muros, os mesmos que sempre encontrou e que a cercaram a vida toda e apenas raramente aconteceu serem derrubados" (BINS, 1986, p. 75). Esses muros, antes erigidos ideologicamente para fornecer-lhe o caminho a trilhar, no momento, adquirem conotação diversa. A exemplo da sua função na cidade antiga, significam uma forma de proteção, por não suportar o dedo em riste da sociedade, acusando-a por não cumprir a bom termo os papéis que lhe são delegados. O autoconfinamento, a rigor, contém em si também uma forma de suicídio.

Isso se deve ao fato de que à condição de reclusão sucede o impedimento do uso da palavra, impossibilitando, tal sucessão, o exercício de comando. Telêmaco comanda e Penélope co-manda ${ }^{14}$. O poder separa-os, e o livre exercício da linguagem é o instrumento

\footnotetext{
${ }^{14}$ Palavras de Telêmaco à Penélope:

Para o teu quarto recolhe-te e cuida dos próprios lavores, roca e tear, e às criadas solícitas ordens transmite para que tudo executem, que aos homens importa a palavra, mormente a mim, a quem cumpre assumir o comando da casa. (HOMERO, 2000, p.38, Canto I, versos 356/359). Grifos meus.
} 
desse poder - político -, conforme Hanna Arendt afirma: "sempre que a relevância do discurso entra em jogo, a questão torna-se política por definição, pois é o discurso que faz do homem ${ }^{15}$ um ser político" (2001, p.11). Acrescenta:

A excelência em si, arete como a teriam chamado os gregos, virtus como teriam dito os romanos, sempre foi reservada à esfera pública, onde uma pessoa podia sobressair-se e distinguir-se das demais. Toda atividade realizada em público pode atingir uma excelência jamais igualada na intimidade; para a excelência, por definição, há sempre a necessidade da presença de outros, e essa presença requer um público formal, constituído pelos pares do indivíduo; não pode ser a presença fortuita e familiar de seus iguais ou inferiores. (ARENDT, 2001, p.58)

Essa situação resume a impossibilidade da convivência inter pares, sem a qual não se proporciona às mulheres organizarem-se como classe, politicamente, através do exercício livre da palavra, devido à reclusão inerente à vida privada. Daí decorre uma das razões da valorização exacerbada do paradigma penelopiano - até nossos dias, pelo que se depreende na literatura - pois, conforme Mircea Eliade, o mito "fornece modelos para o comportamento humano e, por isso mesmo, confere significado e valor à existência” (2000, p.10).

Maria vive, no tempo da juventude, restrita ao âmbito do lar. Não desenvolve atividade remunerada, sequer tenta vender os quadros que pinta. Após o abandono do marido Matheus, tece, ainda na privacidade do domus, malhas de tricô e crochê. Apenas na velhice, mas sempre no (des)aconchego doméstico, para harmonizar-se com seus fantasmas interiores e esperar a morte em paz, engendra os fios de outras vidas, exercendo plenamente a palavra e o decorrente poder de criar, de ser sujeito de seu discurso.

Esse constructo, ou seja, a ação de (auto)construir-se para afirmar-se no mundo público remete, então, a escritora ao nível mais alto da escala social, oportunizando-lhe sobressair-se entre seus pares, além de seu público formal, pois "nenhuma atividade pode tornar-se excelente se o mundo não proporciona espaço para o seu exercício. Nem a educação nem a engenhosidade nem o talento pode substituir os elementos constitutivos da esfera pública, que fazem dela o local adequado para a excelência humana” (ARENDT, 2001, p.59).

Charles Baudelaire atribui também a Flaubert o crédito pela elevação da mulher ao nível (superior) do homem com a criação de Madame Bovary, ao afirmar que: "todas as mulheres intelectualizadas saberão ser-lhe gratas por ter elevado a 'mulherzinha' a um nível (...) em que ela participa da dupla natureza que constitui o homem perfeito: tanto ser capaz de cálculo quanto de devaneio" (apud KOTHE, 1985, p.115). Tal elevação já havia sido realizada antes, nos idos clássicos, quando Penélope, ser virago, alcança a perfeição feminina,

\footnotetext{
15 Faz-se mister relevar que a acepção de homem, na concepção arendtiana, refere-se a toda humanidade, englobando homens e mulheres indistintamente, desprovida da conotação atual de politicamente incorreto, já que sua obra antecede tal conceito.
} 
ao destinar sabiamente o uso da mente do cão e do comportamento do ladrão em estratagemas que lhe possibilitam esperar pelo amado marido.

Por outro lado, a protagonista de Janela do Sonho alinha-se ao que Walter Benjamin comenta acerca de Baudelaire:

Por não ter convicções próprias, [Baudelaire] assumia sempre novas figuras. Flâneur, apache, dandy e trapeiro eram, para ele, outros tantos papéis. Pois o herói moderno não é um herói: apenas representa o papel de herói. A modernidade heróica mostra ser uma tragédia em que o papel de herói está vago. (apud KOTHE, 1985, p. 119)

Da mesma forma, Maria é uma anti-heroína. Ao contrário de Penélope, não se conhece, não sabe seu papel no mundo, não foi boa filha, esposa, mãe, sequer é boa avó (rejeita os netos). Contudo, existe esperança, pois se a filha é morta pela narradora por representar uma continuidade da figura feminina de modo anacrônico, já ultrapassado, é feita concomitantemente a projeção de Maria em três mulheres bem resolvidas, cada uma delas revertendo uma face mal-sucedida da protagonista.

A cidade, portanto, é o lugar propício para a transgressão do mito de Penélope e da ideologia nele contida, pois, a exemplo da mulher - e do homem - que nela habitam, está em constante mutação, fluindo como o rio de Janela do sonho (presumidamente o Guaíba), percorrendo renovadas margens, dentro de um suposto leito perene. A praça, em especial, agora moderno, simboliza o local de luta, vitrine onde se encontram e confrontam homens e mulheres para reivindicar melhores condições de vida. A cidade moderna é uma construção humana voltada para os humanos, erigida em solo profano, cuja condição de proximidade proporciona condições para a mitoclastia da Penélope tradicional, ao mesmo tempo em que favorece o surgimento de novas faces do mito, ressignificando-o.

Além disso, a literatura, o romance em especial, é o espaço adequado para representar todos esses elementos. Tal subversão mítica afina-se ao espírito da modernidade, pois, segundo Marshall Berman:

A experiência ambiental da modernidade anula todas as fronteiras geográficas e raciais, de classe e nacionalidade, de religião e ideologia: nesse sentido, pode-se dizer que a modernidade une a espécie humana. Porém, é uma unidade paradoxal, uma unidade de desunidade: ela nos despeja a todos num turbilhão de permanente desintegração e mudança, de luta e contradição, de ambigüidade e angústia. (BERMANN, 1986, p.15)

Essa unidade paradoxal, ao contrário de se encerrar na carga pseudopessimista que expressa na superficialidade, remete à renovação do espírito de luta na construção de um mundo melhor. O que acontece por trás dessa idéia caótica é a conscientização de que "todas as relações fixas e congeladas são suprimidas" (MARX \& ENGELS apud BERMAN, 1986, p.330) na modernidade, e que a orientação pedagógica cristalizada no mito de Penélope por mais de três milênios perdeu seu lugar. A mulher abandona o gineceu e ganha a rua, se insere 
na cidade, conquista o mundo, com todos os benefícios e prejuízos que tal inserção possa acarretar.

\section{Referências}

ARENDT, Hannah. A condição humana. 10.ed. Rio de Janeiro: Forense Universitária, 2001.

BATAILLE, George. L'erotisme. Paris: Minuit, 1995.

BINS, Patricia. Janela do sonho. Rio de Janeiro: Nova Fronteira, 1986.

BRANDÃO, Junito de Souza. Dicionário mítico-etimológico da mitologia grega. 2.ed. Petrópolis: Vozes, 1991.

BRUNEL, Pierre. Dicionário de mitos literários. (org.). 2.ed. Rio de Janeiro: José Olympio, 1998.

DUMITH, Denise. O mito de Penélope: de Homero a Patricia Bins. 2002.79 p. Monografia (Especialização em Literatura Brasileira Contemporânea), Instituto de Letras, Universidade Federal de Pelotas, Pelotas, 2002.

. O Künstlerroman "Janela do sonho" e a subversão do mito de Penélope. In: Anais do IX Congresso Internacional Abralic 2004 - Travessias. Porto Alegre: Metrópole Indústria Gráfica, 2004.

. "Maríada" - uma odisséia em "Janela do sonho", de Patricia Bins. 2005. 122 p. Dissertação (Mestrado em História da Literatura) - Fundação Universidade Federal do Rio Grande, Rio Grande, 2005.

Penélope. In: BERND, Zilá (org.). Dicionário de figuras e mitos literários das Américas. Porto Alegre: Tomo/Universidade, 2007.

ELIADE, Mircea. Aspectos do mito. Lisboa: Edições 70, 2000.

GENETTE, Gérard. Figures III. Paris: Seuil, 1972.

HESÍODO. Teogonia. A origem dos deuses. 3.ed. São Paulo: Iluminuras, 1995.

HOMERO. Odisséia. Rio de Janeiro: Ediouro, 2000.

IBÁÑEZ, Enrique del Acebo. Sociologia de la ciudad occidental. Un análisis histórico del arraigo. Buenos Aires: Claridad, 1993.

KOTHE, Flávio. (org.). Walter Benjamin. São Paulo: Ática, 1985.

VERNANT, Jean-Pierre. Mito e sociedade na Grécia Antiga. Rio de Janeiro: José Olympio, 1992. Site: http://odisseus-unbound.org/PDFs/Euphrosyne_Review_Portuguese.pdf. Acesso em 01 dez 2006. 